\title{
Reply to Letter to the Editor re: "Unintentional Staining of the Anterior Vitreous with Trypan Blue During Cataract Surgery”
}

\author{
(1) Özcan Kayıkçığlu*, (1) Hüseyin Mayalı*, (1) Suzan Doğruya**, (1) Şenay Alp***, \\ (D) Aydin Alper Yilmazlar****, (D) Emin Kurt* \\ *Celal Bayar University Faculty of Medicine, Department of Ophthalmology, Manisa, Turkey \\ **Uşak Training and Research Hospital, Clinic of Ophthalmology, Uşak, Turkey \\ ***Adiyaman Training and Research Hospital, Clinic of Ophthalmology, Adıyaman, Turkey \\ ****Aydın State Hospital, Aydın, Turkey
}

\section{Dear Editor,}

We thank the authors for their contribution to our study. Unfortunately, we did not have chance to look for toxicity using electrophysiological tests, which might be more sensitive to detect subtle changes in function before morphologically observable derangements. It is probable that a small portion of the trypan dye injected into the anterior chamber reached the anterior vitreous cavity and theoretically was later diluted in about $4.5 \mathrm{cc}$ of vitreous cavity fluid. Although vitrectomy was not performed, on clinical examination this dye disappeared quickly postoperatively. The cases were not routine cataract cases, so we attributed the acuity loss either to primary coexistent disease or difficulty in surgery.

We did not encounter significant retinal changes in fundus examinations and optical coherence tomography postoperatively; however, we cannot completely rule out toxic effects of trypan blue on the retinal cells without electrophysiological tests. This may be a possible cause of the moderate visual acuity levels reached by the patients, as the contributors justifiably mentioned.

Peer-review: Internally peer reviewed.

Authorship Contributions

Surgical and Medical Practices: Ö.K., Concept: Ö.K., H.M., S.D., Ş.A., A.A.Y., E.K., Design: Ö.K., H.M., S.D., Ş.A., A.A.Y., E.K., Data Collection or Processing: Ö.K., S.D., Ş.A., A.A.Y., Analysis or Interpretation: Ö.K., H.M., S.D., Ş.A., A.A.Y., E.K., Literature Search: Ö.K., S.D., Ş.A., A.A.Y., Writing: S.D., Ö.K.

Conflict of Interest: No conflict of interest was declared by the authors.

Financial Disclosure: The authors declared that this study received no financial support.

Address for Correspondence: Suzan Doğruya, Uşak Training and Research Hospital, Clinic of Ophthalmology, Uşak, Turkey E-mail: sdogruya@ hotmail.com ORCID-ID: orcid.org/0000-0002-6822-9077

Received: 12.01.2021 Accepted: 06.03.2021

Cite this article as: Kayıkçığlu Ö, Mayalı H, Doğruya S, Alp Ş, Yılmazlar AA, Kurt E. Reply to Letter to the Editor re: "Unintentional Staining of the Anterior Vitreous with Trypan Blue During Cataract Surgery”. Turk J Ophthalmol 2021;51:256

${ }^{\oplus}$ Copyright 2021 by Turkish Ophthalmological Association Turkish Journal of Ophthalmology, published by Galenos Publishing House. 